\title{
The position of the Rupelian/Chattian boundary in the southern Upper Rhine Graben based on new records of microfossils
}

\author{
Claudius Pirkenseer • Jean-Pierre Berger ${ }^{\dagger} \cdot$ \\ Bettina Reichenbacher
}

Received: 11 March 2013/Revised: 26 August 2013/Accepted: 30 August 2013/Published online: 16 November 2013

(C) Swiss Geological Society 2013

\begin{abstract}
This study analyses the regressive phase of the marine Froidefontaine Subgroup and the subsequent fluviolacustrine Niederroedern formation in the southern Upper Rhine Graben during the Late Rupelian and the position of the Rupelian/Chattian boundary. The study is based on the sedimentary record and several microfossil groups from two boreholes, with a focus on new records of fish otoliths, Bolboforma and Charophyta. The biostratigraphic evaluation of these groups provides evidence for a position of the Rupelian/Chattian boundary within the upper Niederroedern Formation. This is contrary to the results from a previous sedimentological approach, which places the boundary at the base of the Niederroedern Formation. The fish fauna indicates a biogeographic relation to southern France, the Molasse Basin of Switzerland and southern Germany.
\end{abstract}

Keywords Rhine Graben - Biostratigraphy · Oligocene · Charophyta $\cdot$ Fish otoliths $\cdot$ Bolboforma

\section{Abbreviation \\ MHNF Natural history museum of Fribourg}

Editorial handling: K. Grimm \& D. Marty.

\author{
C. Pirkenseer $(\varangle) \cdot$ J.-P. Berger ${ }^{\dagger}$ \\ Unit Earth Sciences, Université de Fribourg, Chemin du Musée \\ 6, 1700 Fribourg, Switzerland \\ e-mail: claudiusmarius.pirkenseer@unifr.ch \\ B. Reichenbacher \\ Department for Earth and Environmental Sciences, \\ Paläontologie und Geobiologie, Ludwig-Maximilians- \\ Universität, Richard-Wagner-Str. 10, 80333 Munich, Germany
}

\section{Introduction}

During the Cenozoic, the Upper Rhine Graben (URG) was characterized by a complex paleogeography and alternate connections (Fig. 1c) to the seas in the South and North (Berger et al. 2005a). In the Rupelian, the transgressionregression cycle of the Froidefontaine Subgroup, previously termed "Série grise" or "Graue Schichtenfolge" is widespread in the URG (Grimm et al. 2011b) and can be related to the global Ru2-3 sequences (Grimm and Grimm 2003; Grimm 2005; Berger et al. 2005a; Roussé 2006; Pirkenseer et al. 2011). In the sediments of the regressive phase (regressive system tract Ru3), marine, coastal, brackish and fluviatile microfossil associations, previously named Meletta-Schichten and Cyrenenmergel, are well known (Fig. 1b). Above follow the fluviatil-lacustrine sediments of the Niederrödern Formation, usually considered as a stratigraphic equivalent of the "Süßwasserschichten" or Jakobsberg Formation in the Mainz Basin (e.g. Grimm 2005; Geyer et al. 2011; Schäfer 2012).

The exact position of the Rupelian/Chattian boundary in URG/Mainz Basin sediments has long been subject of discussion (e.g. Mödden et al. 2000). This boundary was drawn either at the base of the Cyrenenmergel (e.g. Rothausen and Sonne 1984; Hinsken et al. 2007), at the base of the Süßwasserschichten/Niederrödern Fm (Reichenbacher 2000; Roussé 2006) or within the Süßwasserschichten/ Niederrödern Fm (Grimm and Grimm 2003; Grimm 2005; Picot et al. 2008; Grimm et al. 2011a, b; Schäfer 2012). This study provides new biostratigraphical data from the microfossil groups Bolboforma, fish otoliths and Charophyta from the cores of the boreholes DP-202 (north of Mulhouse, France) and Allschwil-2 (southwest of Basel, Switzerland) (see Pirkenseer 2007 for details), which help to solve the question of the precise position of the 

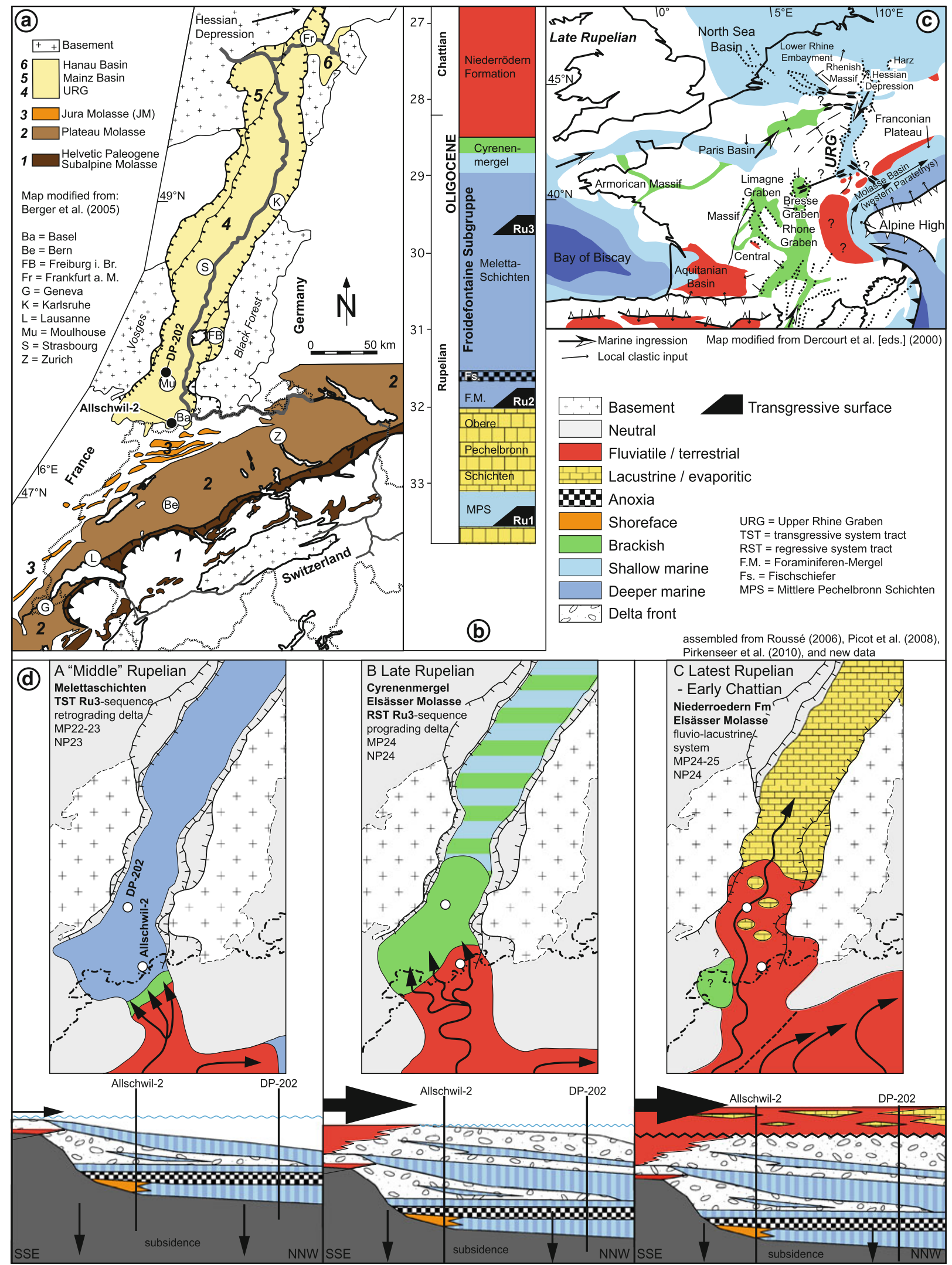
4 Fig. 1 a Geographic overview of the Swiss Molasse Basin and the Upper Rhine Graben. b Simplified Cenozoic sedimentary succession in the southern Upper Rhine Graben. c Palaeogeography of Western Europe during the Late Rupelian. d Palaeogeographical evolution of the southern Upper Rhine Graben and the Swiss Jura Molasse in the Late Rupelian and Early Chattian (assembled from Roussé 2006; Pirkenseer et al. 2011)

Rupelian/Chattian boundary within the succession of the southern URG.

\section{Methods}

60 samples of about $1 \mathrm{~kg}$ from the drillcore DP-202 (north of Mulhouse, France) were treated with hydrogen peroxide at varying concentrations depending on the solubility of the material. Samples were wet-sieved through $63-1,000 \mu \mathrm{m}$ meshes to remove the mud fraction. The residues were then dried at $50{ }^{\circ} \mathrm{C}$. To obtain a maximum diversity of the microfossil assemblages, the entire fractions from 250 to $1,000 \mu \mathrm{m}$ (except for the quartz rich samples) and a sufficient amount of the 63-125 $\mu \mathrm{m}$ material was picked. Examination of fractions was ceased after five barren picking dishes.

The material from the Allschwil-2 core was forwarded as clean, dry residues. Microfossils in samples with increased sand content were enriched by gravity separation methods (chemicals unknown).

Figured specimens were coated with gold and then imaged with a FEI XL30 Sirion FEG scanning electron microscope at maximum resolution with spot size 5 and $20 \mathrm{kV}$ acceleration voltage. The size of the specimens was measured directly during the scanning process.

The material is stored at the Natural History Museum of Fribourg (Switzerland) under collection number 31422-31465.

\section{Geographical and geological context}

The Upper Rhine Graben (URG) represents the central part of the European Cenozoic Rift System (ECRIS) and extends about $300 \mathrm{~km}$ on an approximate North-South axis between the cities of Frankfurt a.M. (W Germany) and Basel (NW Switzerland; Fig. 1a, c) (Dèzes et al. 2004). The crystalline basement of the Odenwald, Vosges and Black Forest mountains and Mesozoic sediments (e.g., Saverne fracture zone, Hardt) border the URG to the east and the west. The Mesozoic tabular and folded Jura Mountains are the boundary of the southern URG. Several hundred meters of Paleogene sediments (Fig. 1b) were deposited during the main rifting phase in the Late Eocene and Rupelian (Dèzes et al. 2004; Sissingh 2006) and are largely covered by Quaternary fluvial sediments of the Rhine River (Grimm et al. 2011b). South of Mulhouse, the Mulhouse High separates the URG in two sub basins, i.e. the Dannemarie Basin in the west and the Sierentz-Wolschwiller Graben in the east (Roussé 2006). Towards the Rhinegraben centre, the grain sizes diminish considerably (Hinsken et al. 2007) and the basin fill consists mainly of lacustrine to marine sands, silts and marls (Berger et al. 2005b).

\section{Rupelian to Early Chattian stratigraphic evolution}

\subsection{Froidefontaine subgroup}

During the late Early Rupelian a widespread marine ingression invaded the entire basin of the Upper Rhine Graben and led to the deposition of the several hundred meters thick Froidefontaine subgroup (also known as Graue Schichtenfolge, Série grise; e.g. Berger et al. 2005b; Grimm et al. 2011b). This succession includes the fossiliferous Foraminiferenmergel (Foraminifera Marls) and the dysoxic to anoxic, finely laminated Fischschiefer (Fish Shales), the latter indicating the maximum flooding and marine conditions throughout the basin (Roussé 2006; Pirkenseer et al. 2011). The overlying succession (Meletta-Schichten) consists of an alternation of marls and fine to medium grained sandstones. Microfossils are scarce both in the Fischschiefer and the Meletta-Schichten. The topmost layer of the Froidefontaine Subgroup is represented by the brackish Cyrenenmergel, deposited in shallow water and well known for a rich and abundant fossil fauna (e.g. Pirkenseer et al. 2010; Grimm et al. 2011b). The transition from the Meletta-Schichten to the Cyrenenmergel is gradual (Pirkenseer and Berger 2011). Roussé (2006) proposed a change from offshore or turbiditic pro-delta sediments to delta-front deposits between the two units. This implies the development of a northward prograding fluvial system (Fig. 1d), which corresponds well with the occurrence of abundant reworked Cretaceous and Eocene planktic Foraminifera (see Roussé 2006; Pirkenseer et al. 2010, 2011). In the southernmost URG and the adjacent Jura Molasse, the upper, sand-dominated brackish part of the Cyrenenmergel is locally represented by a lithological unit termed the "marine Elsässer Molasse" (Fig. 2; e.g. "Molasse alsacienne marine" sensu Roussé 2006). However, due to frequent lateral and temporal facies changes the exact delimitation between the Cyrenenmergel, the Elsässer Molasse (sensu lato) and the Niederrödern Fm is rarely evident (Grimm et al. 2011b).

\subsection{Elsass-subgroup}

The upper Rupelian to Chattian fluvio-lacustrine Niederroedern Formation overlays the Cyrenenmergel, an unconformity is present at its base (Roussé 2006; Grimm 


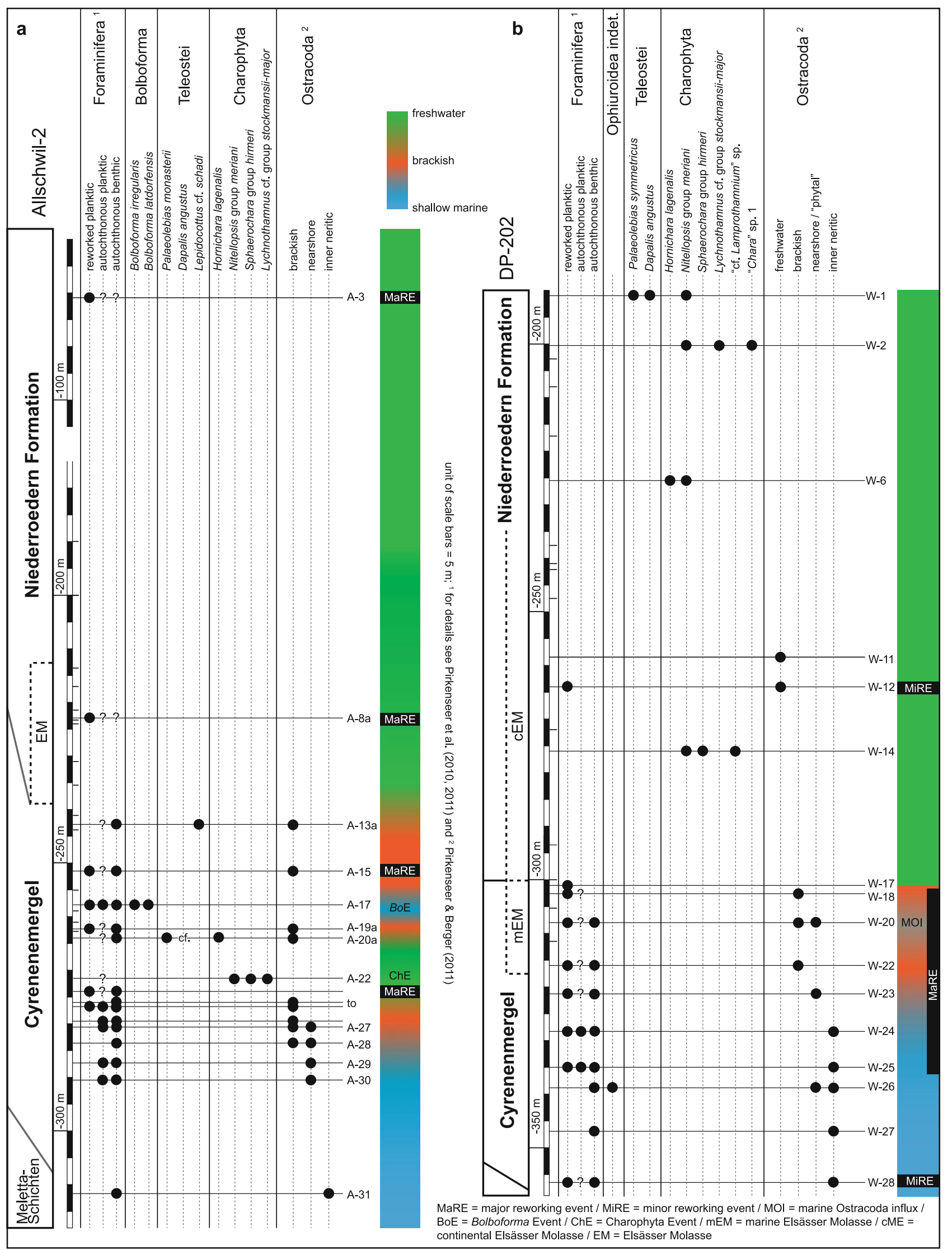


4 Fig. 2 a Log and palaeoecological evolution of the Cyrenenmergel and Niederroedern Formation in the Allschwil-2 drill core and range chart of microfossil records. b Log and palaeoecological evolution of the Cyrenenmergel and Niederroedern Formation in the DP-202 drill core and range chart of microfossil records

et al. 2011b). The Niederroedern Formation comprises trough cross-stratified fluvial sandstones, crevasse splay deposits, floodplain marls and occasional lignitic layers. Its lacustrine, sand-dominated lower part is known as Molasse alsacienne s.s. (or Molasse alsacienne "continentale") in the southernmost URG and adjacent Jura Molasse (Roussé 2006).

\section{Results}

\subsection{Bolboforma}

The two species present were found in a single sample in the upper part of the Cyrenenmergel (Allschwil-2, sample A-17, 257,8 m). They share a globular test of about 110 to $130 \mu \mathrm{m}$ in diameter, a short neck with relatively wide aperture and reticulospinose ornamentation, and can be determined as Bolboforma latdorfensis Spiegler, Spiegler and von Daniels (1991) (see Fig. 3/1) and B. irregularis von Daniels and Spiegler (1974) (see Fig. 3/2). The main difference between them lies in a more regular, hexagonal reticulation of $B$. latdorfensis than seen in B. irregularis (see von Daniels and Spiegler 1974; Pallant and Kaminski 1989; Spiegler and von Daniels 1991; Mackensen and Spiegler 1992; Spiegler and Spezzaferri 2005).

According to Spiegler and Spezzaferri (2005), Bolboforma represent temperate to cool, fully marine conditions and were restricted to middle and higher latitudes. Records of Bolboforma from the URG have been described from the lower Rupelian (NP22) Middle Pechelbronn Beds of the Mainz Basin, where they are associated with a fully marine ostracod assemblage (Griessemer 2002; Grimm et al. 2007). Thus, the occurrence of Bolboforma in sample A-17 (drilling Allschwil-2) suggests a short recurrence of fully marine conditions in the upper part of the Cyrenenmergel.

\subsection{Charophyta}

At Allschwil-2, oogonia are only present in the middle Cyrenenmergel, but this is probably due to the low sample density in the Niederroedern Fm in this core. At DP-202, the first occurrence of charophytes is in the lower Niederroedern Formation. Six species are present and the total species diversity is considerably lower than recorded in Schwarz (1997) for the Cyrenenmergel and Niederroedern Formation in the URG (19 and 18 taxa, respectively). The most common species belongs to the Nitellopsis
(Tectochara) meriani group (Fig. 3/7-9) and occurs in the middle Cyrenenmergel (Allschwil-2) and throughout the Niederroedern Formation (DP-202). Whereas Hornichara lagenalis has been extensively recorded from the URG by Schwarz (1997), the here studied charophytes comprising cf. Lamprothamnium sp. (Fig. 3/4-5), the Sphaerochara hirmeri group (Fig. 3/10) and the Lychnothamnus (Rhabdochara) stockmansii-major group (Figs. 3/11-12, 4/1-3) have not been previously documented from the southern URG. However, the latter two taxa are recorded from the freshwater Molasse near Moutier in the Swiss Jura Mountains (Reichenbacher et al. 1996).

According to Schwarz (1997) the charophyte assemblages from the Cyrenenmergel and Niederroedern Formation conform to the so-called "halophobe association", indicating the progressing desalination of the basin in the Late Rupelian. Based on the presence of Nitellopsis (Tectochara) meriani, the here studied charophyte assemblages also represent a "halophobe association". The single exception is the genus Lamprothamnium, which is adapted to a wide range of salinities (e.g. García and Chivas 2004).

\subsection{Mollusca, higher Crustacea, Echinodermata}

Gastropods and bivalves are generally rare and fragmented in the drill core samples (only limited volume available). Spaniodontella nitida (Fig. 4/4), a small, widely distributed opportunistic infaunal bivalve species (Schneider 2008) occurs in the Cyrenenmergel of both drill cores.

Echinodermata exist mainly in form of small Echinoidea spines (e.g. spatangoid, Fig. 4/6; Kroh and Nebelsick 2010) and a few fragmented interambulacral plates (Fig. 4/5). A mass occurrence of well-preserved Ophiuroidea elements including arm vertebrae and lateral shields was found in the lower Cyrenenmergel at DP-202 (sample W-26; Fig. 4/ 7-8) and confirms fully marine conditions.

\subsection{Fish otoliths (Teleostei)}

Fish otoliths are usually very rare in the Cyrenenmergel and Niederrödern Fm of the URG (Weiler 1963; Reichenbacher 2000). The new material from the studied boreholes indicates the presence of three fish species in the Cyrenenmergel from Allschwil-2, i.e. Palaeolebias monasterii, Dapalis cf. angustus and Lepidocottus cf. schadi (Figs. 2a-b, 4/9-11), whereas two species are present in the Niederroedern Fm of the borehole DP-202, i.e. Palaeolebias symmetricus and again Dapalis angustus (Figs. 2ab, 4/12). These assemblages indicate freshwater to brackish environments (Reichenbacher and Weidmann 1992; Reichenbacher and Schwarz 1997; Reichenbacher and Uhlig 2002; Gierl et al. 2013). Notably, only Lepidocottus schadi 


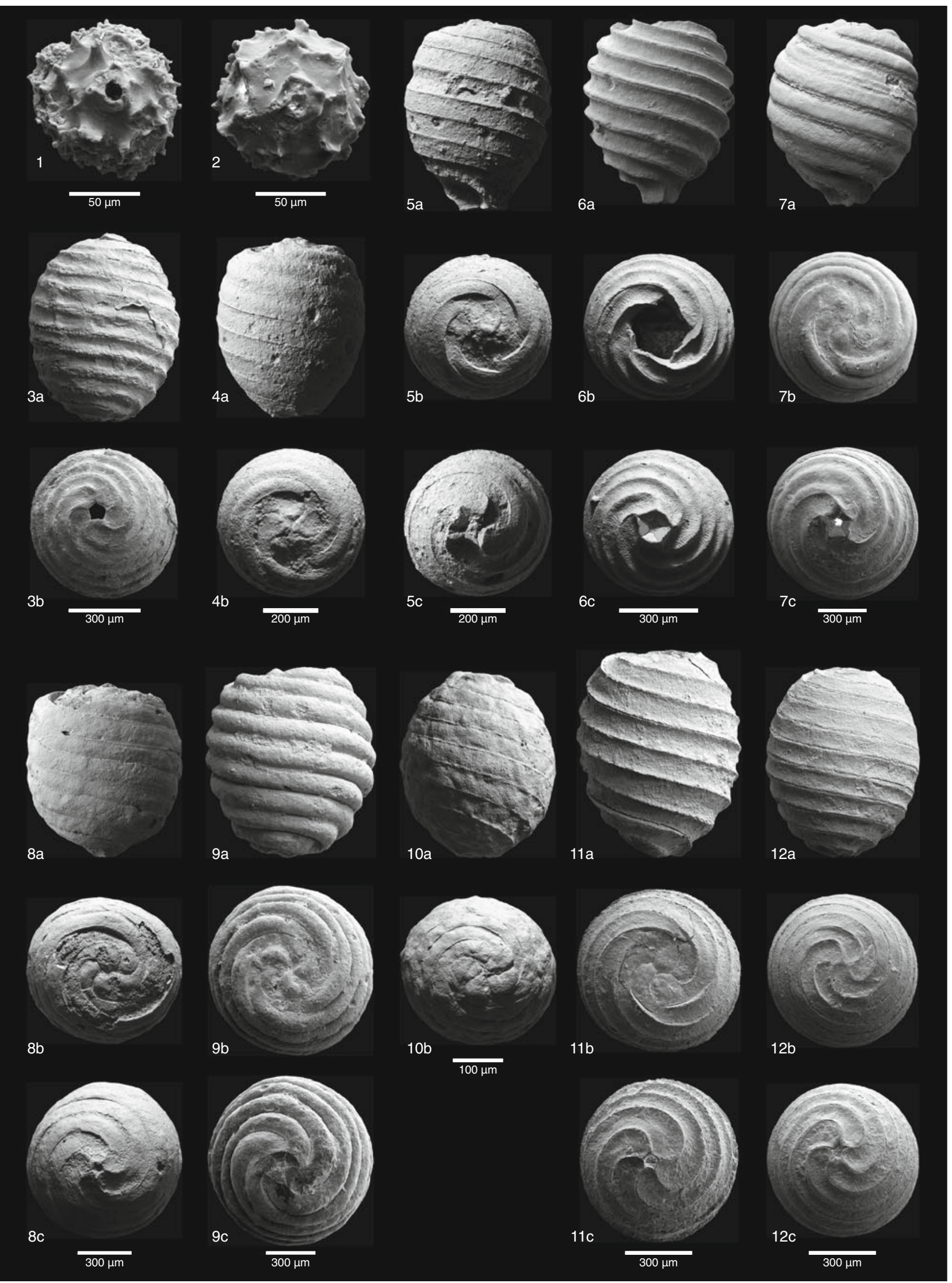


4 Fig. 3 Bolboforma and Charophyta from the studied boreholes. 1 Bolboforma latdorfensis (Allschwil-2, A-17), 2 Bolboforma irregularis (Allschwil-2, A-17; MHNF 31427), 3 "Chara" sp. 1 (DP-202, W-2; MHNF 31466), 4, 5 cf. Lamprothamnium sp. (DP-202, W14; 4: MHNF 31450; 5: MHNF 31451), 6 Hornichara lagenalis (Allschwil2, A-20a; MHNF 31460), 7-9 Nitellopsis (Tectochara) meriani group (7: DP-202, W-2, MHNF 31463; 8: A-22, W-14, MHNF 31461; 9: DP-202, W-2, MHNF 31454), 10 Sphaerochara hirmeri group (Allschwil-2, A-22; MHNF 31462), 11, 12 Lychnothamnus (Rhabdochara) stockmansii-major group (DP-202, W-2; 11: MHNF 31455; 12: MHNF 31465)

has previously been recorded from the URG (Weiler 1963, as Gobius; Reichenbacher 2000, as "genus Eleotridarum"). Palaeolebias symmetricus is known from the Cyrenenmergel of the Mainz Basin (Weiler 1963; Reichenbacher 2000), from Late Rupelian/Early Chattian deposits of the South-German Molasse Basin (Reichenbacher and Schwarz 1997; Reichenbacher and Uhlig 2002; Reichenbacher et al. 2004) and from Late Rupelian sediments of southern France (Reichenbacher and Philippe 1997). The remaining two species are new for the area of the URG and Mainz Basin. Dapalis angustus has been described from the Molasse Basin of western Switzerland and the Jura Molasse, whereas records of Palaeolebias monasterii are restricted to the Jura Molasse (Reichenbacher and Weidmann 1992; Reichenbacher et al. 1996). In conclusion, the fish fauna, even though consisting of only a few species, clearly indicates a biogeographic relation of the southern URG to the Molasse Basin of Switzerland and southern Germany, and also to France.

\section{Palaeoecology}

In the studied boreholes the abundance of benthic foraminifers and ostracods rises significantly with the onset of the Cyrenenmergel (Pirkenseer et al. 2010). The lower Cyrenenmergel starts with shallow marine to polyhaline ostracod assemblages, whereas the abundance of brackish taxa increases strongly towards the top of the Cyrenenmergel (Pirkenseer and Berger 2011). The presence of abundant reworked planktic foraminifera taxa in the middle to upper Cyrenenmergel confirms fluvial influence. Predominantly brackish conditions are clearly indicated in the upper half of the Cyrenenmergel at the drill site Allschwil2, but only in the upper third at DP-202 (Fig. 2a-b).

At Allschwil-2, a major reworking event follows the rather abrupt decrease of salinity in the lower third of the Cyrenenmergel, and precedes two charophyte-dominated samples (A-22, A-23). This implies a first transition to fluvial and stagnant freshwater conditions, probably due to a shifting lobe of the prograding delta to the south (Fig. 1d). A final short recurrence of more marine conditions in the upper part of the Cyrenenmergel is indicated by the occurrence of Bolboforma in Allschwil-2. Another major reworking event (sample A-15), brackish ostracods and increasingly sandy deposits herald the final transition to the fluvial environment of the Niederroedern Formation (around sample A-13 to A-10).

At DP-202, a longer lasting reworking event "accompanies the more gradual transition from a marine to brackish environment in the upper half of the Cyrenenmergel. A final short recurrence of more marine conditions in the upper part of the Cyrenenmergel is indicated by the influx of nearhore/ "phytal" ostracod taxa (Pirkenseer and Berger 2011). At DP-202 the unconformity between the Cyrenenmergel and the Niederroedern Fm is distinct. In the Niederroedern Fm, from sample W-16 onwards, the occurrences of charophytes and lacustrine ostracods (Fig. 2b) from the marly floodplain deposits (Roussé 2006) confirms the development of a freshwater ecosystem at DP-202.

\section{Biostratigraphy (Fig. 5)}

\subsection{Froidefontaine subgroup}

The results from the planktic foraminifera in the two boreholes are difficult to interpret due to the presence of seemingly autochthonous, but possibly also reworked taxa (e.g. Chiloguembelina cubensis, Subbotina utilisindex) (Pirkenseer et al. 2010). Accordingly, the Froidefontaine Subgroup deposits should not be younger than the Late Rupelian planktic zone (mid?) P21a/O4 (Pirkenseer et al. 2010).

\subsection{Cyrenenmergel}

The Bolboforma species indicate a Late Rupelian to Early Chattian age corresponding to nannoplankton zone NP24 (Spiegler and Spezzaferri 2005). The otolith assemblage, however, supports a correlation to the Early Rupelian otolith zone OT-O1 based on the presence of Dapalis angustus and Palaeolebias monasterii (Reichenbacher 1999).

\subsection{Niederroedern formation}

As true index species like Chara microcera and Stephanochara ungeri are missing in the charophyte record of the studied boreholes, the biostratigraphic interpretation relies on the ranges of Hornichara lagenalis and the Lychnothamnus (Rhabdochara) stockmansii-major group. Berger (1999) proposed the FOD (first occurrence date) of $H$. lagenalis as biostratigraphically important and correlated it to the Early Chattian (transition between the mammal units MP 25/MP 26). Meanwhile, however, Hornichara lagenalis has been found to extend into the Late Rupelian (MP 


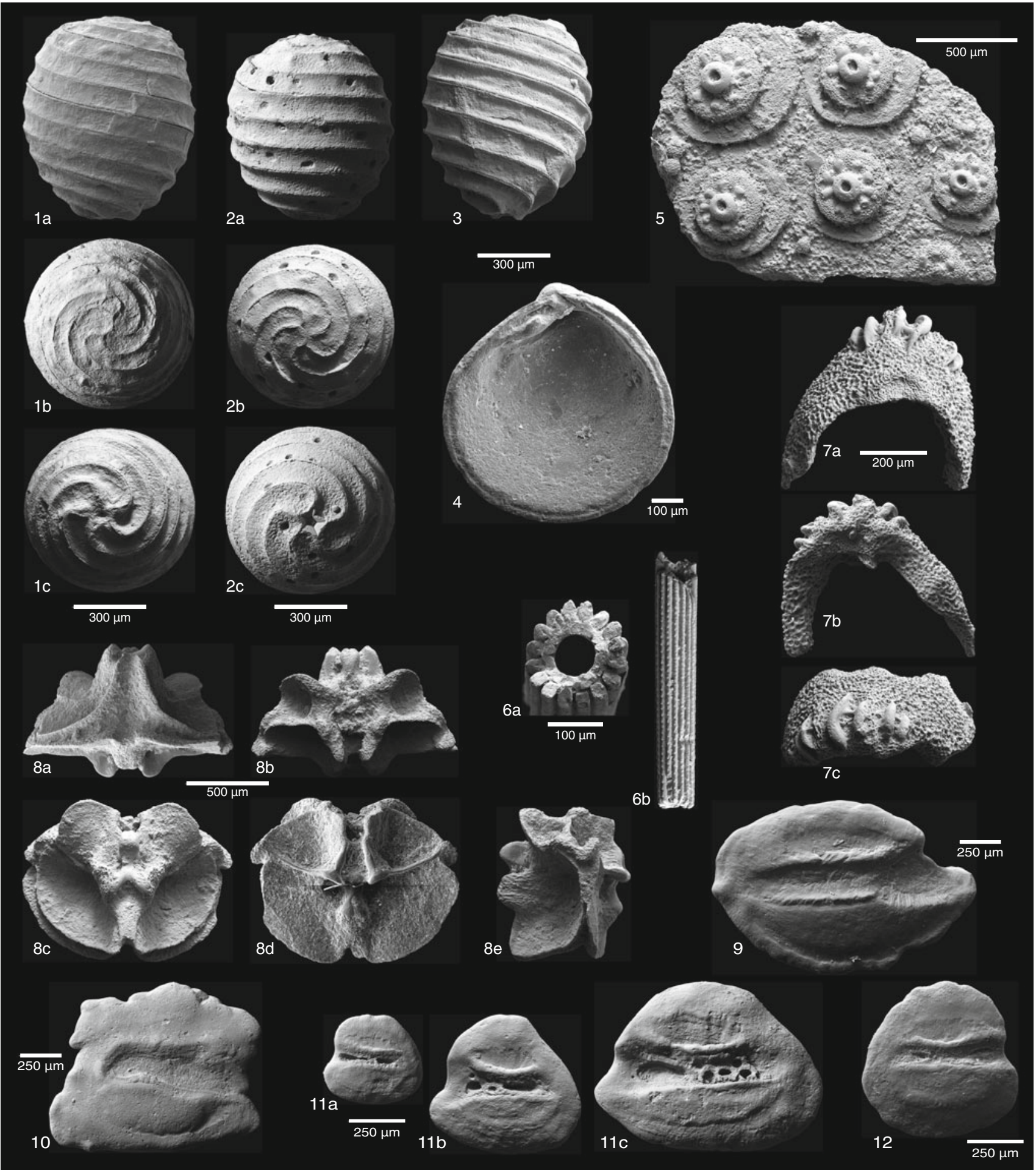

Fig. 4 Charophyta, Bivalvia, Echinodermata and Teleostei (otoliths) from the studied boreholes. 1-3 Lychnothamnus (Rhabdochara) stockmansii-major group (1 \& 3: DP-202, W-2, MHNF 31459 \& MHNF No for 3 missing; 2: Allschwil-2, A-22, MHNF 31449), 4 Spaniodontella nitida (Allschwil-2, A-26; MHNF 31422), 5 Interambulacral plate (DP-202, W-26), 4/6 Spatangoid spine (DP-202, W-20),
7 Ophiuroidea indet., lateral shield (DP-202, W-26; MHNF 31430), 8 Ophiuroidea indet., arm vertebra (DP-202, W-26; MHNF 31437), 9 Dapalis angustus (DP-202, W-1; MHNF 31442), 10 Lepidocottus $\mathrm{cf.}$ schadi (Allschwil-2, A-13a; MHNF 31441), 11 Palaeolebias monasterii (Allschwil-2, A-20a; MHNF 31438-40), 12 Palaeolebias symmetricus (DP-202, W-1; MHNF 31443) 


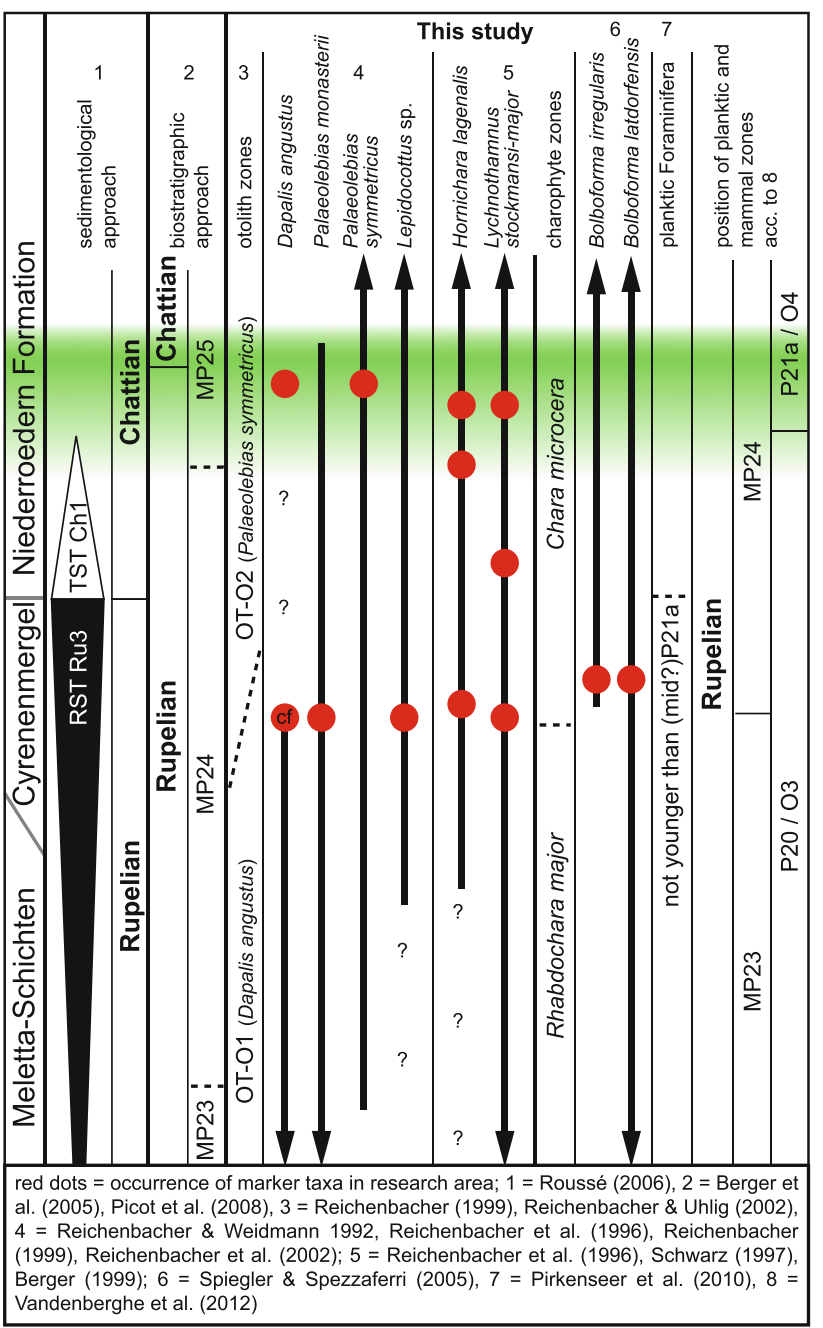

Fig. 5 Integrated biostratigraphic interpretation of the studied boreholes

24) (Schwarz 1997), and, with a large gap also occurs around the Eocene/Oligocene boundary. The last (common) occurrence date (LOD) of the L. (R.) stockmansiimajor group is in the Early Chattian (MP 25).

However, the presence of otoliths of Palaeolebias symmetricus co-occurring with Dapalis angustus provide clear support for a Late Rupelian age for the Niederrödern Fm, near the boundary of the otolith zones OT-O1/OT-O2 and mammal units MP23/MP24, respectively (Reichenbacher 1999; Reichenbacher et al. 2004). As a consequence, the Rupelian/ Chattian boundary cannot be located at the base of the Niederrödern Fm, but is most likely positioned within the Niederrödern Fm.

\section{Discussion}

The position of the Rupelian/Chattian boundary in the "Süßwasserschichten" (equivalent of the Niederroedern
Fm) of the Mainz Basin has been investigated in detail by Mödden et al. (2000). In this study, the "Süßwasserschichten" have been attributed to the Late Rupelian/Early Chattian transition zone based on mammals and otoliths, indicative for MP 24 and OT-O2, respectively. However, according to Vandenberghe et al. (2012) zone MP 24 lies entirely within the Late Rupelian. This indicates that the "Süsswasserschichten" studied by Mödden et al. (2000) still represent the Late Rupelian, and that the Rupelian/ Chattian boundary can be assumed to lie somewhere within the "Süsswasserschichten", which agrees well with our results that parts of the Niederroedern Fm are Late Rupelian in age. In contrast, Roussé (2006) correlated the Rupelian/Chattian boundary to the unconformity between the Cyrenenmergel and the Niederroedern Formation. However, reinterpretation of short-term sequence boundaries as proposed in Roussé (2006), shifting the RST Ru3/ TST Ch1 boundary upwards in the sedimentary succession, would be a possible solution of this problem.

The different spatiotemporal sedimentary and tectonic evolution of the Molasse Basin, Swiss Jura Molasse, URG and the Mainz Basin (extending over several hundreds of $\mathrm{km}$ ) complicates the comparison of depositional environments and sediments that appear to represent similar time spans (see Kempf et al. 1999; Kempf and Pross 2005; Berger 2011 for the Swiss Molasse Basin). The Swiss Molasse Basin attained an overfilled state in the Late Rupelian, resulting in fluvial transport of alpine sediments to the area of the southern URG (Berger et al. 2005a; Roussé 2006; Pirkenseer et al. 2011). This probably established migratory pathways for freshwater fish, allowing Dapalis angustus to reach the URG in the Late Rupelian.

\section{Conclusions}

The biostratigraphical analysis of Bolboforma, charophytes and otoliths from the boreholes Allschwil-2 and DP 202 in the southern Upper Rhine Graben clearly indicates the position of the Rupelian/Chattian boundary within the Niederroedern Formation. This result agrees well with biostratigraphical data from palaeogeographically adjacent areas (Mödden et al. 2000; Picot et al. 2008; Berger 2011). The palaeogeographic and palaeoenvironmental evolution during the Cyrenenmergel shows regional disparities, as evidenced by a charophyte and Bolboforma signal at the locality Allschwil-2, that have not been recorded further to the north at DP-202. This may be explained by quickly shifting coastlines during delta progradation in the southern Upper Rhine Graben.

Acknowledgments The authors wish to express gratitude to Simon Schneider (Vienna) for determination of the mollusk material, to 
Andreas Kroh (Vienna) for the investigation of the echinoderm specimens and to Silvia Spezzaferri (Fribourg) for providing literature and discussion concerning Bolboforma. Two anonymous reviewers are thanked for constructive remarks.

\section{References}

Berger, J.-P. (1999). Redefinition of European oligo-miocene charophyte biozonation. Australian Journal of Botany, 47, 283-296.

Berger, J.-P. (2011). Du Bassin molassique au fossé rhénan: évolution des paléoenvironnements dans un avant pays dynamique. Géochronique, 117, 47-49.

Berger, J.-P., Reichenbacher, B., Becker, D., Grimm, M., Grimm, K., Picot, L., et al. (2005a). Paleogeography of the Upper Rhine Graben (URG) and the Swiss Molasse Basin (SMB) from Eocene to Pliocene. International Journal of Earth Sciences, 94, 697-710.

Berger, J.-P., Reichenbacher, B., Becker, D., Grimm, M., Grimm, K., Picot, L., et al. (2005b). Eocene-Pliocene time scale and stratigraphy of the Upper Rhine Graben (URG) and the Swiss Molasse Basin (SMB). International Journal of Earth Sciences, 94, 711-731.

Dercourt, J., Gaetani, M., Vrielynck, B., Barrier, E., Biju-Duval, B., Brunet, M.F., Ed(s) (2000). Peri-Tethys palaeogeographical Atlas. Commission for the Geological Map of the World (24 maps, scale 1: 10’000’000, explanatory notes, 269 pp.) Paris.

Dèzes, P., Schmid, S. M., \& Ziegler, P. A. (2004). Evolution of the European Cenozoic rift system: Interaction of the Alpine and Pyrenean orogens with their foreland lithosphere. Tectonophysics, 389, 1-33.

García, A., \& Chivas, R. A. (2004). Quaternary and extant euryhaline Lamprothamnium Groves (Charales) from Australia: Gyrogonite morphology and paleolimnological significance. Journal of Paleolimnology, 31, 321-341.

Geyer, M., Nitsch, E., \& Simon, T. (Eds.). (2011). Geologie von Baden-Württemberg (p. 627). Stuttgart: Schweizerbart Science Publishers.

Gierl, C., Reichenbacher, B., Gaudant, J., Erpenbeck, D., \& Pharisat, A. (2013). An extraordinary gobioid fish fossil from Southern France. PLoS ONE, 8, e64117. doi:10.1371/journal.pone. 0064117.

Griessemer, T.W. (2002). The Bolboforma signal. In Proceedings of the 8th Biannual Meeting of RCNNS/RCNPS, 57-66.

Grimm, M. (2005). Beiträge zur Lithostratigraphie des Paläogens und Neogens im Oberrheingebiet (Oberrheingraben, Mainzer Becken, Hanauer Becken). Geologisches Jahrbuch Hessen, 132, 79-112.

Grimm, K.I. \& Grimm, M.C. (2003). Geologischer Führer durch das Mainzer Tertiärbecken. In K. I. Grimm., M. C. Grimm., O. Neuffer., H. Lutz., (Eds.), Die fossilen Wirbellosen des Mainzer Tertiärbeckens. Mainzer Naturwissenschaftliches Archiv, Beihefte ( Vol. 26) 1-158.

Grimm, K.I., Grimm, M., Radtke, G., Kadolsky, D., Schäfer, P., Franzen, J.L., et al. (2011a). Mainzer Becken. In Deutsche Stratigraphische Kommission (Ed.), Stratigraphie von Deutschland IX. Tertiär, Teil 1. Schriftenreihe der Deutschen Gesellschaft für Geowissenschaften (Vol. 75) 133-209.

Grimm, K. I., Radtke, G., \& Spiegler, D. (2007). Foraminiferen und Bolboformen aus den Mittleren Pechelbronn-Schichten (tieferes Unter-Oligozän) der Bohrung Wallau B98-BK5. Geologische Abhandlungen Hessen, 116, 157-171.

Grimm, M., Wielandt-Schuster, U., Hottenrott, M., Grimm, K.I., Radtke, G. Berger, J.-P., et al. (2011b). Oberrheingraben. In Deutsche Stratigraphische Kommission (Ed.), Stratigraphie von
Deutschland IX. Tertiär, Teil 1. Schriftenreihe der Deutschen Gesellschaft für Geowissenschaften (Vol.75) 57-131.

Hinsken, S., Ustaszewski, K., \& Wetzel, A. (2007). Graben width controlling syn-rift sedimentation: The Palaeogene southern Upper Rhine Graben as an example. International Journal of Earth Sciences, 96, 979-1002.

Kempf, O., Matter, A., Burbank, D. W., \& Mange, M. (1999). Depositional and structural evolution of a foreland basin margin in a magnetostratigraphic framework: the eastern Swiss Molasse Basin. International Journal of Earth Sciences, 88, 253-275.

Kempf, O., \& Pross, J. (2005). The lower marine to lower freshwater Molasse transition in the northern Alpine foreland basin (Oligocene; central Switzerland-south Germany): Age and geodynamic implications. International Journal of Earth Sciences, 94, 160-171.

Kroh, A., \& Nebelsick, J. H. (2010). Echinoderms and Oligo-Miocene carbonate systems: potential applications in sedimentology and environmental reconstruction. International Association of Sedimentology Special Publication, 42, 201-228.

Mackensen, A., \& Spiegler, D. (1992). Middle Eocene to early pliocene Bolboforma (Algae?) from the Kerguelen Plateau, southern Indian Ocean. Proceedings of the Ocean Drilling Program, Scientific Results, 120, 675-682.

Mödden, C., Schäfer, P., Reichenbacher, B., Schwarz, J., \& Kadolsky, D. (2000). Säugetiere, Fisch-Otolithen, Ostracoden, Mollusken und Charophyten aus den Süßwasser-Schichten (Oligozän) von Wolfsheim im Mainzer Becken. Paläontologische Zeitschrift, 74, 343-361.

Pallant, A., \& Kaminski, M. A. (1989). Bolboforma from leg 105, Labrador Sea and Baffin Bay, and the chronostratigraphy of Bolboforma in the North Atlantic. Proceedings of the Ocean Drilling Program, Scientific Results, 105, 381-385.

Picot, L., Becker, D., Cavin, L., Pirkenseer, C., Lapaire, F., Rauber, G., et al. (2008). Sédimentologie et paléontologie des paléoenvironnements côtiers des dépôts de l'UMM rhénane dans le Jura suisse. Swiss Journal of Geosciences, 101, 483-513.

Pirkenseer, C. (2007). Foraminifera, Ostracoda and other microfossils of the Southern Upper Rhine Graben-Palaeoecology, biostratigraphy, palaeogeography and geodynamic implications. Dissertation, Université de Fribourg, Fribourg, Switzerland, p. 340.

Pirkenseer, C., \& Berger, J.-P. (2011). Paleogene Ostracoda from the southern Upper Rhine Graben: taxonomy, palaeoecology and palaeobiogeography. Palaeontographica, Abteilung A, 295, $1-149$.

Pirkenseer, C., Spezzaferri, S., \& Berger, J.-P. (2010). Palaeoecology and biostratigraphy of the Paleogene foraminifera from the southern Upper Rhine Graben and the influence of reworked planktonic foraminifera. Palaeontographica, Abteilung A, 293, $1-93$.

Pirkenseer, C., Spezzaferri, S., \& Berger, J.-P. (2011). Reworked microfossils as a paleogeographic tool. Geology, 39, 843-846.

Reichenbacher, B. (1999). Preliminary otolith-zonation in continental Tertiary deposits of the Paratethys and adjacent areas. Neues Jahrbuch für Geologie und Paläontologie Abhandlungen, 214, 375-390.

Reichenbacher, B. (2000). Das brackisch-lakustrine Oligozän und Unter-Miozän im Mainzer Becken und Hanauer Becken: fischfaunen, Paläoökologie, Biostratigraphie, Paläogeographie. Courier Forschungsinstitut Senckenberg, 222, 1-143.

Reichenbacher, B., Berger, J.-P., \& Weidmann, M. (1996). Charophytes et otolithes de la Molasse d'eau douce inférieur oligocène de Moutier (Jura suisse). Neues Jahrbuch für Geologie und Paläontologie, 202, 63-93.

Reichenbacher, B., \& Philippe, M. (1997). Les otolithes de Téléostéens oligocènes du bassin d'Apt (Vaucluse, France). 
Neues Jahrbuch für Geologie und Paläontologie, Abhandlungen, 203, 391-423.

Reichenbacher, B., \& Schwarz, J. (1997). Charophyten und Otolithen aus den Cyrenen-Schichten des nördlichen Alpenvorlandes. Paläontologische Zeitschrift, 71, 173-188.

Reichenbacher, B., \& Uhlig, U. (2002). Die Fischfauna der chattischen Unteren Cyrenen-Schichten in der Murnauer Mulde (süddeutsche Faltenmolasse). Courier Forschungsinstitut Senckenberg, 237, 175-191.

Reichenbacher, B., Uhlig, U., Kowalke, T., Bassler, B., MatzkeKarasz, R., \& Schenk, B. (2004). Biota, palaeoenvironments and biostratigraphy of continental Oligocene deposits of the south German Molasse Basin (Penzberg syncline). Palaeontology, 47, 639-677.

Reichenbacher, B., \& Weidmann, M. (1992). Fisch-Otolithen aus der oligo-/miozänen Molasse der West-Schweiz und der Haute Savoie (Frankreich). Stuttgarter Beiträge zur Naturkunde, B, 184, 1-83.

Rothausen, K., \& Sonne, V. (1984). Mainzer Becken. In Sammlung geologische Führer (Vol.79), p. 203. Berlin-Stuttgart : Borntraeger.

Roussé, S. (2006). Architecture et dynamique des séries marines et continentales de l'Oligocène Moyen et Supérieur du Sud du Fossé Rhénan: Evolution des milieux de dépôt en contexte de rift en marge de l'avant-pays alpin. Dissertation, Université Louis Pasteur, Strasbourg, Alsace, p. 471.

Schäfer, P. (2012). Mainzer Becken. Sammlung geologische Führer (2nd ed., Vol. 79), p. 333. Berlin-Stuttgart: Borntraeger.
Schneider, S. (2008). The bivalve fauna from the Ortenburg Marine Sands in the well-core "Straß" (Early Miocene; SE Germany) taxonomy, stratigraphy, paleoecology, and paleogeography. Paläontologische Zeitschrift, 82, 402-417.

Schwarz, J. (1997). Charophyten aus dem Tertiär des Oberrheingrabens (Mitteleozän - Untermiozän). Palaeontographica, Abteilung B, 243, 1-84.

Sissingh, W. (2006). Kinematic sequence stratigraphy of the European Cenozoic Rift System and Alpine Foreland Basin: correlation with Mediterranean and Atlantic plate-boundary events. Netherlands Journal of Geosciences, 85, 77-129.

Spiegler, D., \& Spezzaferri, S. (2005). Bolboforma-an overview. Paläontologische Zeitschrift, 79, 167-181.

Spiegler, D., \& von Daniels, C. H. (1991). A stratigraphic and taxonomic atlas of Bolboforma (protophytes, incertae sedis, Tertiary). Journal of Foraminiferal Research, 21, 126-158.

Vandenberghe, N., Hilgen, F. J., \& Speijer, R. P. (2012). The Paleogene period. In F. Gradstein, J. Ogg, M. Schmitz, \& G. Ogg (Eds.), The geologic time scale 2012 (pp. 855-921). Amsterdam: Elsevier.

von Daniels, C. H., \& Spiegler, D. (1974). Bolboforma n. gen. (Protozoa ?) -ine neue stratigraphisch wichtige Gattung aus dem Oligozän/Miozän Nordwestdeutschlands. Paläontologische Zeitschrift, 48, 57-76.

Weiler, W. (1963). Die Fischfauna des Tertiär im oberrheinischen Graben, des Mainzer Beckens, des unteren Maintales und der Wetterau, unter besonderer Berücksichtigung des Untermiozäns. Abhandlungen der Senckenbergischen naturforschenden Gesellschaft, 504, 1-75. 